American Journal of Agricultural and Biological Sciences 6 (1): 122-127, 2011

ISSN 1557-4989

(C) 2010 Science Publications

\title{
Evaluation of Hevea brasiliensis (Latex Timber Clone: RRIM 2001 and RRIM 3001) in Relation to Different Water Stress
}

\author{
Shafar Jefri Mokhatar, Wan Noordin Daud and Nursyazwina Md Zamri \\ Department of Crop Science, Faculty of Agriculture, Universiti Putra Malaysia, \\ 43400 UPM Serdang, Selangor, Malaysia
}

\begin{abstract}
Problem statement: Rubber, Hevea brasiliensis, has been traditionally planted in the humid tropics, which is characterized by high rainfall throughout the year. However, due to an increase in world's demand for rubber, future planting will be established in dry areas, characterized by prevalence water stress. Utilizing limited resource, in dry areas or to use water wisely is very important. This study provides a detail evaluation of morphological and physiological responses of rubber trees at nursery stage in relation to different water stress. Approach: Two new latex timber clones from Malaysia Rubber Board (MRB), RRIM 2001 and RRIM 3001 were used in this study. Five levels of treatment were used; plants irrigated for every two days, five days, 10 days, 15 days and everyday which acted as control. The experimental design used was a Completely Randomized Block Design (RCBD) with four replications. Results: Fundamental changes of plant growth and physiological responses showed that treatment with well watered for clone RRIM 2001 (T1) had higher values than other treatments. Harvest index highest in well watered (T1) with mean 20.73, while T5 were lowest with the mean 5.03. Stomata conductance showed significant difference between $\mathrm{T} 6$ with $0.161 \mu \mathrm{mol} \mathrm{m}^{-2} \mathrm{~s}^{-1}$ compared to under stress treatments with 0.00 $\mu \mathrm{mol} \mathrm{m} \mathrm{m}^{-2} \mathrm{~s}^{-1}$. There was treatment failure to adapt to water stress at treatments withholding water for 15 days followed by treatments 10days and five days. Conclusion: RRIM 2001 and RRIM 3001 clones had responded to water stress by indicating changes in morphological and physiological responses. This indicated that Hevea brasiliensis cannot withstand water stress.
\end{abstract}

Keywords: Rubber, Hevea brasiliensis, Latex Timber Clones (LTC), water stress, growth, physiological responses, Completely Randomized Block Design (RCBD)

\section{INTRODUCTION}

Hevea brasiliensis, originated from Brazil have been widely planted in South East Asia. Nowadays, the usage of rubber has become more increasingly important in daily life. This scenario has triggered rubber planting to be shifted to marginal areas, such as dry areas (Noordin, 2009). Water has been a very important resource to agriculture since the issues of global warming and climate change arise. Water is scarce and its quality is decreasing in many parts of the world (Gholizadeh et al., 2010; Fuller and Harhay, 2010; Raviv and Blom, 2001). Pertaining to water as an invaluable resource, there is a need to use this source wisely. Water deficit stress can be defined as a situation in which plant water potential and turgor are reduced to interface with normal functions (Shao et al., 2008). Plant water status is also affected by reducing of water availability in plant. More than that, water stress influences plant growth at various levels, including cell community (Al-Taisan, 2010; Blumwald et al., 2004; Colom and Vazzana, 2001). The quantity and quality of plant growth depend on cell division enlargement and differentiation and all of these events are affected by water stress (Cabuslay et al., 2002; Correia et al., 2001). It also reduced plant growth inhibition of various physiological and biochemical processes such as photosynthesis, respiration translocation, ion uptake, carbohydrate, nutrients metabolism and hormone (Bhatt and Srinivasa, 2005; Chaitanya et al., 2003; Blum, 1996).

Latex Timber Clones (LTC) are clones with high latex yield and rubberwood production. They exhibit good growth, good growth vigour and posses long straight boles. These clones are suitable for the production of latex and rubberwood or production of rubberwood (Malaysian Rubber Board, 2009). The parental of clone RRIM 2001 is RRIM 600 x PB 260. The laminae is elliptical obovate. Color of foliage is light green, semi glossy and smooth. Clone RRIM 3001 has an elliptical shape. The color of foliage is dark

Corresponding Author: Wan Noordin Daud, Department of Crop Science, Faculty of Agriculture, Universiti Putra Malaysia, 43400 UPM, Serdang, Selangor, Malaysia e-mel:wnordin@agri.upm.edu.my 
shining green. Both clone are recommended for both latex and timber production (Malaysian Rubber Board, 2009).

Soil from Munchong series are widely planted with rubber in Malaysia. The Munchong series soil is suitable for rubber plants and it has been classified as first class soil for rubber in term of soil-crop suitability (Malaysian Rubber Board, 2009). Different types of soil influences the growth performance of the crop (Heryati et al., 2010). Munchong series soil is silty clay loam to silty clay with yellowish brown to strong brown. The structure of this soil series is moderate to strong fine and medium sub-angular blocky. In term of USDA soil taxonomy, Munchong Series has been classified as very fine, Typic Hapludox. In the $\mathrm{FAO}$ /UNESCO Legend, this soil has been classified as Haplic Ferrasol (Ogos, 1993).

\section{MATERIALS AND METHODS}

Plant materials and experimental treatments: This study was carried out under rain shelter, Field 2 at Universiti Putra Malaysia, Serdang, Selangor, Malaysia. The source of rubber clone was from Malaysia Rubber Board (MRB) and consists of three month rootstock from clone RRIM 2001 and RRIM 3001. The plants were selected according to the average height and girth. Polythene bags size used was $40 \mathrm{~cm} \mathrm{x}$ $45 \mathrm{~cm}$ which can withhold the planting media up to $10 \mathrm{~kg}$. The media used was Munchong soil series. Sources of fertilizer are RISDA 1 fertilizer consisting of $10 \% \mathrm{~N}, 16 \% \mathrm{P}, 9 \% \mathrm{~K}$ and $2.5 \% \mathrm{Mg}$. RISDA 1 is recommended by Rubber Industry Smallholders Development Authority for young rubber. Study about fertilizer on Latex Timber Clones has proved rubber plants will scorched and dead if overfertilized (Mokhatar and Daud, 2011).

Treatments 1 to 5 (T1 until T5) were from RRIM 2001, while treatments 6 to 10 (T6 until T10) were from RRIM 3001. For water stress treatments, various water frequencies by varying number of days was applied. Treatments comprised the control as well watered (T1 and T6), withholding water for two days (T2 and T7), withholding water for five days (T3 and T8), withholding water for 10days (T4 and T9) and withholding water for 15 days (T5 and T10).

Water requirement determination: water requirement was determined by measuring water retention of the soil using a pressure chamber and the pressure plate. A core ring measuring about 7.6 and $4.0 \mathrm{~cm}$ in diameter and depth, respectively and having known weight was hammered into the soil to ring depth. The samples retaining rings placed on each of the four porous plates for $1,10,33$ and $1500 \mathrm{kPa}$ pressure. The core (undisturbed) sample was broken up into five pieces of equal sizes. One piece of sample in retaining ring was placed on each of the porous plates. For the 0 bar pressure (saturation), the samples is placed in a retaining ring on a coarse wire mesh. All ceramic plates were saturated for 24 hours by keeping the water level just below the edge of the ring. The plate with samples was placed inside the corresponding pressure chamber. The plate was connected to the outflow tube. The chamber was closed and pressure applied. Equilibrium was attained when no more outflows occurs. A period of 4-7 days is usually sufficient to achieve moist soil. The chamber opened, the samples removed and each of them was weighed (Wa). The sample oven-dried at $105^{\circ} \mathrm{C}$ for 24hours and each of the soil samples weighed again $(\mathrm{Wb})$. The calculation for volumetric water content was: $\left(\mathrm{m}^{3} \mathrm{~m}^{-3}\right), \theta \mathrm{v}=(\mathrm{Wa}-\mathrm{Wb}) / \mathrm{Wb} \times \rho_{\mathrm{b}}$, where $\rho_{b}=$ bulk density, $\mathrm{Wa}=$ dry weight, $\mathrm{Wb}=$ oven dried sample after dry weight.

Data collection: Height: plant height was measured from the soil level until the top of the plant shoot.

Girth: girth circumference was measured $10 \mathrm{~cm}$ from the soil level.

Dry weight: The leaf, stem and root were cut and placed in the 'Hot Air Oven' at $60^{\circ} \mathrm{C}$ for $48-72$ hours. After that, the weights were determined using a weighing machine.

Harvest index: The harvest index is the ratio of economical yield to the biological yield and biological yield includes root weight (Gardner et al., 1985)' The calculation was; Harvest index, $(\mathrm{HI})=$ Economical yield/Biological yield x 100 .

Leaf area: Leaf area was measured by using the LI3100 Area meter. The total leaves collected were measured for their total leaf area. Photosynthesis rate: The rate of photosynthesis had been measured by Portable Photosynthesis System Model LICOR-6200. The fully expanded leaves were selected to measure the photosynthesis rate.

Experimental design and data analysis: The study was conducted in a completely randomized block design with four replications. Each block comprised of 30 plants and each treatment consists of three samples (polythene bags). There were two clones consisting of five treatments per clone. Analysis Of Variance (ANOVA) on data obtained was performed using 
Am. J. Agri. \& Biol. Sci., 6 (1): 122-127, 2011

Statistical Analysis System (SAS 9.1, SAS Institute, Inc. Cary NC. USA). Least Significant Different (LSD) test at $\mathrm{p}<0.05$ was employed for mean comparison.

\section{RESULTS}

Water requirement: Figure 1 shows moisture content at saturation $(0.1 \mathrm{kPa})$, field capacity $(33 \mathrm{kPa})$ and permanent wilting points $(1500 \mathrm{kPa})$ for sample are $0.365, \quad 0.255$ and $0.205 \mathrm{~m}^{3} \mathrm{~m}^{-3}$ respectively. The available water content for plant use is the difference between field capacity and permanent wilting point . The available water content for plant used was 0.255 $0.20 .5=0.05 \mathrm{~m}^{3} \mathrm{~m}^{-3}$. The amount of water used for $10 \mathrm{~kg}$ of Munchong soil series in this study is $0.5 \mathrm{~L}$.

Growth responses: Differences in water stress affected the growth response of Hevea brasiliensis (Table 1). These results showed that the plants gave positive responses when they were provided with enough water, while the plant growth were inhibited, the plants were stunted and dead under severe water stress condition.

Table 1: Growth responses of Hevea brasiliensis under water stress

\begin{tabular}{cccc}
\multicolumn{3}{c}{ condition } \\
Treatment & $\begin{array}{c}\text { height } \\
(\mathrm{cm})\end{array}$ & $\begin{array}{c}\text { girth } \\
(\mathrm{cm})\end{array}$ & $\begin{array}{r}\text { Total leaf area } \\
\left(\mathrm{cm}^{2}\right)\end{array}$
\end{tabular}

\begin{tabular}{lll}
\multicolumn{1}{c}{$(\mathrm{cm})$} & $(\mathrm{cm})$ & $\left(\mathrm{cm}^{2}\right)$ \\
\hline RRIM 2001 & & \\
well watered (T1) 68.33a & $2.30 \mathrm{a}$ & 1358.6a \\
RRIM 2001 & &
\end{tabular}

withholding water

for two days (T2) $\quad 62.10 \mathrm{ab} \quad 2.03 \mathrm{~b} \quad 639.2 \mathrm{bc}$

RRIM 2001

withholding water

for five days (T3)

RRIM 2001

withholding water

$\begin{array}{llll}\text { for 10days (T4) } \quad 0.00 \mathrm{c} & 0.00 \mathrm{~d} & 0.0 \mathrm{~d}\end{array}$

RRIM 2001

withholding water

$\begin{array}{llll}\text { for } 15 \text { days (T5) } & 0.00 \mathrm{c} & 0.00 \mathrm{~d} & 0.0 \mathrm{~d}\end{array}$

RRIM 3001

well watered (T6) 60.33ab 2.13a $\quad 896.8 \mathrm{~b}$

RRIM 3001

withholding water

for two days (T7) $\quad 57.67 \mathrm{~b} \quad 2.03 \mathrm{~b} \quad 724.8 \mathrm{bc}$

RRIM 3001

withholding water

for five days (T8) $\quad 58.67 \mathrm{~b} \quad 1.70 \mathrm{c} \quad 400.5 \mathrm{~cd}$

RRIM 3001

withholding water

$\begin{array}{llll}\text { for 10days (T9) } & 0.00 \mathrm{c} & 0.00 \mathrm{~d} & 0.00 \mathrm{~d}\end{array}$

RRIM 3001

withholding water

for 15days (T10) $\quad 0.00 \mathrm{c} \quad 0.00 \mathrm{~d} \quad 49.5 \mathrm{~d}$

$\begin{array}{llll}\mathrm{LSD}_{0.05} & 9.60 & 0.19 & 411.85\end{array}$

Values in each column with same letter did not differ significantly at $\mathrm{p}<0.05$ according to LSD

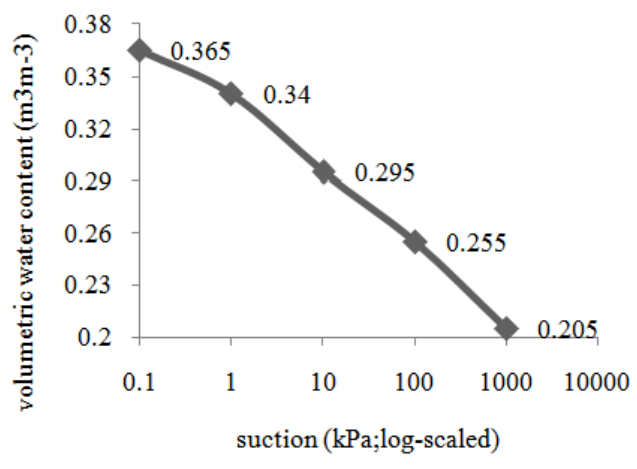

Fig. 1: Soil water retention curve

Table 2: Dry matter productions of Hevea brasiliensis under water stress condition

\begin{tabular}{cccc}
\hline $\begin{array}{c}\text { Treatment } \\
\text { dry dry }\end{array}$ Leaf & Stem Root & $\begin{array}{c}\text { Total } \\
\text { dry }\end{array}$ & dry \\
weight weight weight & weight
\end{tabular}

\begin{tabular}{cccc}
$(\mathrm{g})$ & $(\mathrm{g}) \quad(\mathrm{g}) \quad(\mathrm{g})$ \\
\hline
\end{tabular}

RRIM 2001
well watered (T1) 5.73ab $\quad 8.39 \mathrm{a}$ $25.42 \mathrm{ab} \quad 39.54 \mathrm{a}$

RRIM 2001

withholding water

for two days (T2) $\quad 4.87 \mathrm{~b} \quad 4.17 \mathrm{~b} \quad 13.97 \mathrm{cde} 23.00 \mathrm{bc}$

RRIM 2001

withholding water

for five days (T3) $0.53 \mathrm{~d} \quad 4.10 \mathrm{~b} \quad 18.67 \mathrm{~cd} \quad 23.30 \mathrm{bc}$

RRIM 2001

withholding water

for 10days (T4) $\quad 0.00 \mathrm{~d} \quad 0.95 \mathrm{~d} \quad 17.5 \mathrm{cde} \quad 18.45 \mathrm{c}$

RRIM 2001

withholding water

for 15 days (T5) $\quad 0.00 \mathrm{~d} \quad 1.23 \mathrm{~cd} \quad 19.45 \mathrm{bc} \quad 20.68 \mathrm{bc}$

RRIM 3001

well watered (T6) 6.53a $6.00 \mathrm{ab} \quad 26.00 \mathrm{a} \quad 38.53 \mathrm{a}$

RRIM 3001

withholding water

for two days (T7) $\quad 5.05 \mathrm{~b} \quad 4.48 \mathrm{~b} \quad 20.16 \mathrm{ab} \quad 29.70 \mathrm{~b}$

RRIM 3001

withholding water

for five days (T8) $\quad 2.74 \mathrm{c} \quad 3.77 \mathrm{~b} \quad 13.00 \mathrm{de} \quad 19.50 \mathrm{c}$

RRIM 3001

withholding water

for 10days (T9)

$16.53 \mathrm{c}$

RRIM 3001

$0.00 \mathrm{~d} 0.97 \mathrm{~d} \quad 15.56 \mathrm{cde} \quad 16.53 \mathrm{c}$

withholding water

$\begin{array}{llll}\text { for } 15 \text { days (T10) } & 0.81 \mathrm{~d} 3.24 \mathrm{bcd} & 12.13 \mathrm{e} & 16.19 \mathrm{c}\end{array}$

$\begin{array}{lllll}\mathrm{LSD}_{0.05} & 1.40 & 2.77 & 6.28 & 7.12\end{array}$

Values in each column with same letter did not differ significantly at $\mathrm{p}<0.05$ according to LSD

Table 2 showed that well watered (T1) gave the highest means, while treatment withholding water for 15 days (T10) were under stressed showed slightly lower mean. From this data, T1 and T6 gave the higher values of total dry weight which means the plant growth steadily according to leaf, stem and root dry weight.

Figure 2 showed that well watered treatment (T1) gave the highest mean of harvest index among 


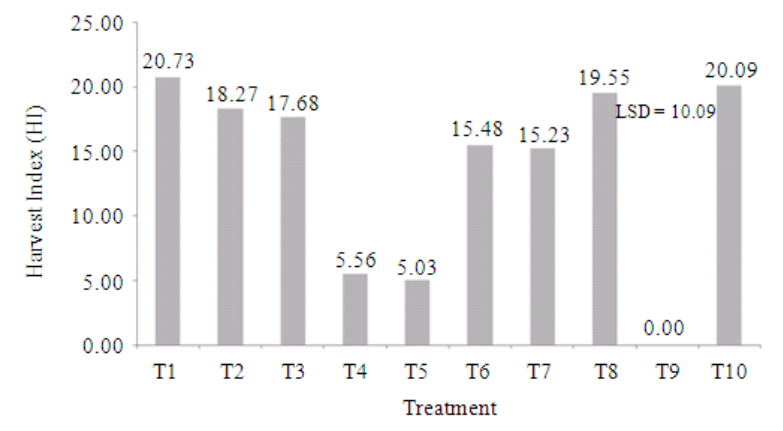

Fig. 2: Effect of water stress on Harvest Index (HI)

Table 3: Physiological responses of Hevea brasiliensis under water stress condition

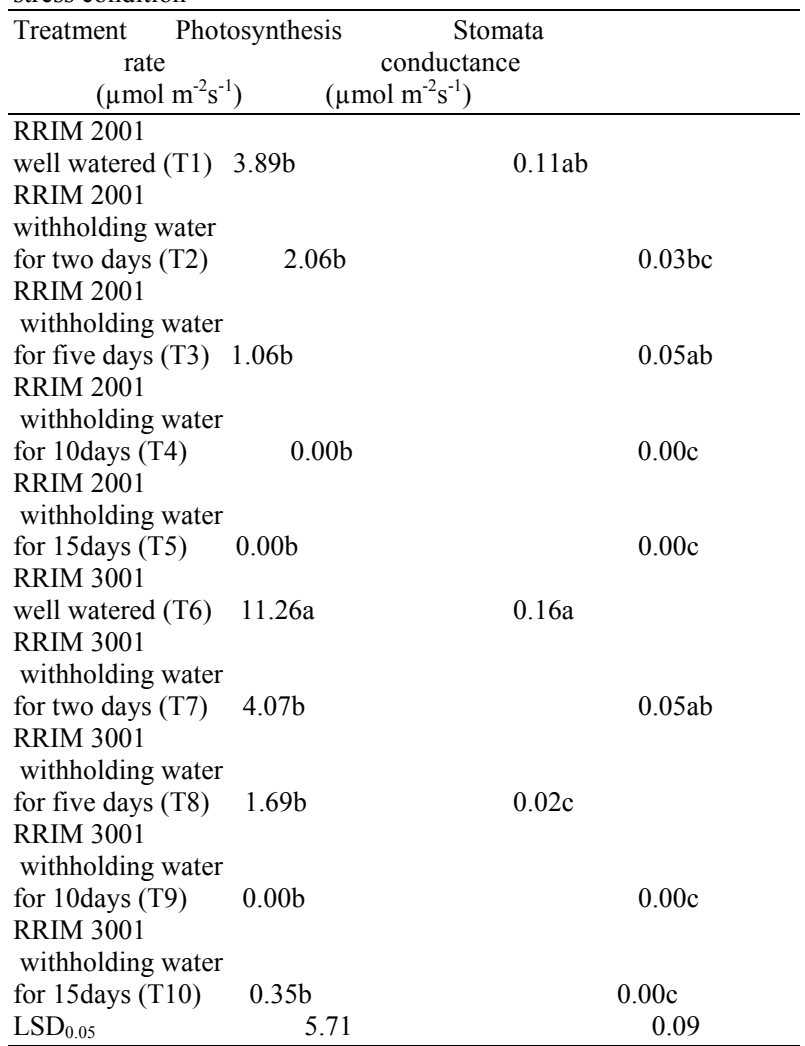

Values in each column with same letter did not differ significantly at $\mathrm{p}<0.05$ according to LSD

treatments with the mean 20.73, while T5 (withholding water for 15days) with the mean 5.03 was the lowest.

Physiological responses: Photosynthesis rate of well watered plants showed that T6 from clone RRIM 3001 were significantly higher than T1 (RRIM 2001).

From Table 3, the highest mean of stomata conductance among treatments was T6 (well watered) with the mean $0.161 \mu \mathrm{mol} \mathrm{m} \mathrm{m}^{-2}$, while the lowest

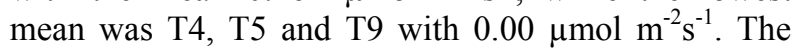

leaves were falling and became chlorosis after 2 weeks of treatments for $\mathrm{T} 4, \mathrm{~T} 5$ and $\mathrm{T} 9$.

\section{DISCUSSION}

Growth responses: The previous study about Abelmochus esculentus under water stress has showed decline in the cell enlargement and more leaf senescence. These prove that water stress was a very important limiting factor at the initial phase of plant growth (Shao et al., 2008). Water stress also results in reduction of leaf area, where the leaf growths were inhibited and the older leaves fell down (Anyia and Herzog, 2004). Reduction of expansion of young leaves and loss of older leaves caused a decreased in the LAR in the stressed plants (Paknejad et al., 2009).

The stem dry weight reduced with increasing of water stress because of girth circumference reduction and plant death. Water stress condition affected the plant dry matter translocation, which occurred in the photosynthesis process. The allocation of dry matter will be enhanced to the root, to enhance water uptake for survival under drought stress (Leport et al., 2006). The limitation of the size of the source and sink tissue were not only effects from drought stress, the other phenomenon such as the phloem loading, assimilates translocation and dry matter partitioning was also impaired by drought stress (Haghighi et al., 2010).

The results indicated that harvest index and the end products of photosynthesis decreased under water stress condition. Other study on peanut with several soil water levels also gave the same results on harvest index (Songsri et al., 2009).

Physiological responses: Photosynthesis process was inhibited when the water was not enough to translocate sucrose and hexose to the leaves as a sink and this was showed by the lowest value in the Table 3. Under water stress condition, photosynthesis pigments and compounds changed ( Anjum et al., 2003), apparatus damaged (Fu and Huang, 2001) and activities of enzymes in Calvin cycle also diminished, which lead to reduction in crop yield.

Internal water deficits results reduction of stomata conductance (Zhao et al., 2010). This was caused by root volumes restrictions rather than a general shortage of soil moisture level. Oxygen levels limitation might also trigger the root to shoot signal via chemical means.

\section{CONCLUSION}

From the results, it can be concluded that the two clones of rubber, RRIM 2001 and RRIM 3001 had 
responded to water stress by indicating changes in morphological and physiological responses. The changes in those aspects showed that treatment with well watered procedure for clone RRIM 2001(T1) had high values than other treatments. In water deficit condition, plant growth, photosynthesis rate and dry matter production were reduced. The results also showed that rubber plant cannot withstand water stress and dry areas.

\section{ACKNOWLEDGEMENT}

The authors would like to thank Universiti Putra Malaysia for the post-graduate grant and also the Ministry of Science, Technology and Innovation, Malaysia, for the research grant, Fundamental Research Grant Scheme (FRGS), No 01-11-08-665FR, in supporting the research study.

\section{REFERENCES}

Anjum, F., M. Yaseen, E. Rasul, A. Wahid and S. Anjum, 2003. Water stress in barley (Hordeum vulgare L.). Effect on chemical composition and chlorophyll content. Pak. J. Agric. Sci., 40: 45-49.

Al-Taisan, W.A., 2010. Comparative effects of drought and salt stress on germination and seedling growth of pennisetum divisum (gmel.) Henr. Am. J. Applied Sci., 7: 640-646. DOI: 10.3844/AJASSP.2010.640.646

Anyia, A.O. and H. Herzog, 2004. Water-use efficiency, leaf area and leaf gas exchange of cowpeas under mid-season drought. European J. Agronomy, 20: 327-339. DOI: 10.1016/S11610301(03)00038-8

Bhatt, R.M., N.K.R. Srinivasa, 2005. Influence of pod load on response of okra to water stress. Indian J. Plant Physiol., 10: 54-59.

Blum, A., 1996. Crop responses to drought and the interpretation of adaptation. Plant Growth Regulation, 20: 135-148. DOI: 10.1007/BF00024010

Blumwald, E., G. Anil and G. Allen, 2004. New directions for a diverse plant. Proceedings of the 4th International Crop Science Congress, Sept. 26Oct. -1, CDROM, Brisbane, Australia, pp: 1-20.

Cabuslay, G.S., O. Ito and A.A. Alejal, 2002. Physiological evaluation of responses of rice (Oryza sativa L.) to water deficit. Plant Sci., 163: 815-827. DOI: 10.1016/S0168-9452(02)00217-0

Chaitanya, K.V., P.P. Jutur, D. Sundar and R.A. Reddy, 2003. Water stress effect on photosynthesis in different mulberry cultivars. Plant Growth Regulation, 40: 75-80. DOI: 10.1023/A:1023064328384
Colom,M.R. and C. Vazzana, 2001. Drought stress effects on three cultivars of eragrostis curvula: Photosynthesis and water relations. Plant Growth Regulation, 34: 195-202. DOI: 10.1023/A:1013392421117

Correia, M.J., D. Coelho and M.M. David, 2001. Response to seasonal drought in three cultivars of ceratonia siliqua: Leaf growth and water relation. Tree Physiol., 21: 645-653.

$\mathrm{Fu}$, J. and B. Huang, 2001. Involvement of antioxidants and lipid peroxidation in the adaptation of two cool-season grasses to localized drought stress. Environ. Exp. Bot, 45: 105-114. DOI: 10.1016/S0098-8472(00)00084-8

Fuller, A.C. and M.O. Harhay, 2010. Population growth, climate change and water scarcity in the southwestern United States. Am. J. Environ. Sci., 6: 249-252. DOI: 10.3844/ajessp.2010.249.252

Gardner, F.P., R.B. Pearce and R.L. Mitchell, 1985. Physiology of Crop Plants. 1st Edn., The Iowa State University Press, ISBN-10: 081381376X, USA., pp: 327.

Gholizadeh, A., M.S.M. Amin, A.R. Anuar, M. Esfahani and M.M. Saberioon, 2010. The study on the effect of different levels of zeolit and water stress on growth, development and essential oil content of moldavian balm (Dracocephalum moldavica L.). Am. J. Applied Sci., 7: 33-37. DOI: 10.3844/AJASSP.2010.33.37

Haghighi, B.J., Z. Yarmahmodi and O. Alizadeh, 2010. Evaluation the effects of biological fertilizer on physiological characteristic and yield and its components of corn (Zea mays L.) under drought stress. Am. J. Agric. Bio. Sci., 5: 189-193. DOI: 10.3844/AJABSSP.2010.189.193

Heryati, Y., D. Belawan, A. Abdu, M.N. Mahat and H. Abdul-Hamid et al., 2010. Growth performance and biomass accumulation of a khaya ivorensis plantation in three soil series of ultisols. Am. J. Agric. Biol. Sci., 6: 33-44. DOI: 10.3844/ajabssp.2011.33.44

Leport, L., N.C. Turner, R.J. French, M.D. Barr and R. Duda et al., 2006. Physiological response of chickpea genotype to terminal drought in a mediterranean type environment. European J. Agronomy, 11: 279-291. DOI: 10.1016/S11610301(99)00039-8

Malaysian Rubber Board, 2009. Rubber Plantation and Processing Technologies. Kuala Lumpur. Malaysian Rubber Board. http://vital.lgm.gov.my/vital/access/manager/Colle ction/vital1:78300;jsessionid=B19F7BF76836E944 BA3B6188B586FF08 
Mokhatar, S.J. and W.N. Daud, 2011. Evaluation of Straight Fertilizer, Urea (AGRENAS) and Ammonium Sulphate, on Hevea brasiliensis (RRIM2000). J. Sci. Technol. Tropics, 7: 1-7.

Ogos, 1993. Panduan Mengenali Siri-siri Tanah Utama Di Semenanjung Malaysia. Jabatan Pertanian. http://www.pertanianperak.gov.my/jpp/images/pdf/ panduan \%20tanah\%20utama.pdf

Paknejad, F., M. Mirakhori, M.J. Al-Ahmadi, M.R. Tookalo and A.R. Pazoki et al., 2009. Physiological response of soybean (Glycine max) to foliar application of methanol under different soil moistures. Am. J. Agric. Biol. Sci., 4: 311-318. DOI: 10.3844/AJABSSP.2009.311.318

Raviv, M. and T.J. Blom, 2001. The effect of water availability and quality on photosynthesis and productivity of soilless-grown cut roses. Scientia Horticulturae, 88: 257-276. DOI: 10.1016/S03044238(00)00239-9
Shao, H.B, L.Y. Chu, C.H. Jaleel and C.H. Zhao, 2008. Water-deficit stress-induced anatomical changes in higher plants. Comput. Rendus Biol., 331: 215225. DOI: 10.1016/J.CRVI.2008.01.002

Songsri, P., S. Jagloy, C.C. Holbrook, T. Kesmala and N. Vorasoot et al., 2009. Association of root, specific leaf area and spad chlorophyll meter reading to water use efficiency of peanut under different available soil water. Agric. Water Manage., $\quad 96$ : 790-798. $\quad$ DOI: 10.1016/J.AGWAT.2008.10.009

Zhao, D., B. Glaz and J.C. Comstock, 2010. Sugarcane response to water-deficit stress during early growth on organic and sand soils. Am. J. Agric. Biol. Sci., 5: 403-414. DOI: 10.3844/AJABSSP.2010.403.414 